\title{
Effects of Materialism on Well-Being: A Review
}

\author{
Harshmeet $\operatorname{Kaur}^{1} *$, Ramanpreet $\operatorname{Kaur}^{2}$
}

\section{ABSTRACT}

Materialism as a research topic has gained currency for over past two decades. Studies reveal that in consumer societies, people are trying to capture happiness and satisfaction in the form of possession of luxury goods. Materialism is characterized by a pursuit of wealth taking precedence over higher level needs. Well-being is a comprehensive term for the psychological, physical, social, or economic state of an individual or group. The researchers have found evidence to support the belief that materialism shares a negative relationship with wellbeing. Several researches have documented that materialistic lifestyle is allied with low subjective wellbeing. In light of past researches, this paper attempts to review the literature to trace this relationship between these two variables. The overall argument of the paper is that materialistic tendencies are detrimental to the well being of an individual. The paper concludes with the research directions to carry the research on materialism and well being forward.

\section{Keywords: Materialism, Well Being, Happiness, Life Satisfaction}

"It is the preoccupation with possessions, more than anything else that prevents us from living freely and nobly."

Bertrand Russel ('Principles of social reconstructions, 1916).

In consumer societies, material goods are considered an index of happiness and success (Garðarsdóttir \& Dittmar, 2012). Consumers are consuming today more than they ever have before (Van Boven \& Gilovich, 2003). Research evidence demonstrates that materialistic values have risen dramatically in last few decades, (Astin et al. 2002; Ger \& Belk, 1999). It is a widely held belief in consumer societies that materialism is good for the economy of the nation, since materialism pushes people to work more to secure higher incomes, to increase consumption of goods and services and promotes living standards (Kasser et al., 2007; Richins \& Rudmin, 1994). Material possessions are socially meaningful not only owing to their instrumentality in sustaining and developing our lives but also because they are used as the symbols of identity, personality and self-expression (Dittmar \& Pepper, 1994; Dittmar, 1992; Burroughs et al.,1991; Kamptner,

\footnotetext{
${ }^{1}$ Research Scholar, Department of Psychology, Panjab University, Chandigarh, India

${ }^{2}$ Research Scholar, Department of Psychology, Panjab University, Chandigarh, India

*Responding Author

(C) 2016 I H Kaur, R Kaur; licensee IJIP. This is an Open Access Research distributed under the terms of the Creative Commons Attribution License (http://creativecommons.org/licenses/by/2.0), which permits unrestricted use, distribution, and reproduction in any Medium, provided the original work is properly cited.
} 


\section{Effects of Materialism on Well-Being: A Review}

1991). It is a matter of growing concern that materialism is distracting the individuals, especially the youth, from self-development and responsibilities they owe to their community (Csikszentmihalyi, 1999).

Critiques attack marketing and advertising for causing affluenza (de Graff et al., 2005). Affluenza, a term coined from affluence and influenza highlights the excessive craving for material possessions. De Graaf et al. (2001) define it as a 'painful, contagious sociallytransmitted condition of overload, debt, anxiety, and waste resulting from the dogged pursuit of more". Consumption is interlinked with the creation and production of a sense of self as possessions help us convey our connection to others and express who we think we are (McCracken, 1986; Levy, 1981). Brewer and Porter (1993) observed that our lives today are overloaded with the material objects which bring with them their prospects as well as the problems.

Social thinkers link materialism with the squandering away of valuable resources, deterioration of traditional religious values, and also the breakdown of civic responsibility (Schudson, 1991). It has become an activity that they engage in to cater to their hedonistic needs (Ramnathan \& Menon, 2006; O’Cass \& McEween, 2004; Faber \& O’Guinn, 1989). Some look at their new purchases as a means to fill a void in their lives (Diener et al., 1993; Belk, 1985). The notion that consumer goods are a sure-shot to success, identity and happiness is the core value of a consumer society (Dittmar \& Drury, 2000). Dittmar (2007) maintained that material possessions have acquired a disproportionate focus in the lives of individuals in the consumer societies. In a capitalist society, human beings are consumers by nature (Solomon et al., 2004).

Researchers have been trying to understand the influence of Terror Management Theory on consumer behavior (Fransen et al., 2008; Arndt et al., 2004; Rindfleish \& Burroughs, 2004). The value individuals ascribe to consumer items seems to change owing to terror management processes. For example, death reminders make long-term status items such as investments etc. more desirable. In a study conducted by Fransen et al. (2008), the results revealed that when reminded of death, people buy items that are valued in their cultures. Globalization is another great force behind the current consumer trends. It is manifested in the form of global flows across the world. Appadurai (1990) maintained that there are five types of global flows -

- mediascapes (image and communication),

- ethnoscapes (tourists, migrants and foreign students),

- ideoscapes (political ideas and ideologies),

- technocapes (technology and know-how), and

- finanscapes (capital and money).

Craig et al. (2009) maintain that cultural products and lifestyles from the developed world are spreading across developing countries through traditional and social media, and is influencing 


\section{Effects of Materialism on Well-Being: A Review}

consumer tastes, shopping preferences and purchase behavior of consumers (Douglas \& Craig, 1997). This phenomenon also seems to be changing the fabric of societies as lifestyles, products, and rituals of one culture are being absorbed into and adopted by another culture (Craig et al., 2009, Craig \& Douglas, 2006).

The cultures with individualism and materialism as their defining qualities affect well-being through their influence on values. Defining values, it can be said that they are a core component of a culture, the characteristics of a society and its institutions, as well as of its people (Eckersley, 2005; 2001). The cultural significance of goods is evident from their ability to take upon a meaning through their use as markers of that culture (Dittmar, 1992).

\section{Materialism}

Materialism has gained widespread attention across the globe for its far reaching and rather gripping effects on the consumer psyche. It can be defined as "the importance ascribed to the ownership and acquisition of material goods in achieving major life goals" (Richins, 2004). Acquisition desires can be traced back to early civilizations (Belk, 1985). Noting the importance of materialism, Twitchell (1999) stated, "of the $20^{\text {th }}$ century's various- isms, it has been the one that has ultimately triumphed”. Dittmar et al. (2014), in a meta-analysis defined materialism as the long-term endorsement of materialistic values, goals or beliefs which revolve around acquiring money and possessions that convey status.

The word "materialism" finds its roots in philosophy (Micken and Roberts, 1999). It is the philosophical conceptualization that nothing exists except matter and its movement (Scott, 2009). A highly materialistic individual believes that the acquisition of material goods is central to happiness and self-definition, and an indicator of success (Richins \& Dawson, 1992).

Materialism serves as a topic of research in different disciplines and is defined from different perspectives as a way of life, as a value orientation, a cultural system, a personality trait, a second order value, and as an aspiration (Bindah \& Othman, 2011). Belk (1984) defines materialism as 'the importance a consumer attaches to worldly possession'. It is conceived as a complex trait which reflects the centrality which an individual ascribes to possessions (Belk, 1985). Richins and Dawson (1992) identified three dimensions to materialism: centrality, happiness, and success. Richins and Dawson (1992) suggest that materialism is a value. A value is "a belief that a specific mode of conduct is personally or socially preferable to other beliefs and that it has a transcendental quality that guides actions, attitudes, judgments, comparisons across specific objects and situations, and beyond immediate goals” (Richins \& Dawson, 1992).

Wiedmann et al. (2009) defined materialism as the degree to which individuals find possessions to play a central role in their life. Individuals higher on materialism are more likely to acquire 


\section{Effects of Materialism on Well-Being: A Review}

possessions, to have positive attitudes towards acquisition, and to assign a higher priority to material goods (Wiedmann et al. 2009). Researchers maintain that materialism as a phenomenon is bound to grow in all cultures irrespective of the type of the economies, even in the lack of material goods (Ger and Belk, 1996; Parker et. al., 2010) and it will also grow when material goods are available in abundance (Schaefer et al., 2004). Richins (1994a, 1994b) argued that the individuals high on materialism choose possessions that are publicly visible and prominent and bring them prestige. These individuals are also strongly influenced by the opinions of others when selecting products. Researchers observed that materialism exhibits a positive relationship with the preference for goods that symbolize prestige and social status (Prendergast \& Wong, 2003; Holt, 1998; Wong \& Ahuvia, 1998). Materialism is a socio cultural (Ghadrian, 2010; Schor \& Holt, 2000) as well as an individual phenomenon (Lim et al., 2012; Chang \& Arkin, 2002; Kasser, 2002; Larsen et al., 1999).

\section{Well Being}

Well-being is a comprehensive term for the psychological, physical, social, or economic state of an individual or group (Scott et al., 2014; Diener 2009; Malhotra 2006; Sirgy \& Lee 2006). A major proposition in psychology is that wellbeing is not simply the lack of mental illness (Seligman \& Csikszentmihalyi, 2000). Seligman (2011), in his PERMA model of flourishing, defined psychological well-being in terms of five domains: positive emotions (P), engagement (E), relationships (R), meaning (M), and accomplishment (A). Positive emotions refer to feelings of happiness, engagement means feeling psychologically connected, invested in activities, relationships implies the feeling of being connected and supported by others, meaning refers to the feeling that one's life is meaningful, valuable, and feeling connected to something greater than oneself, and accomplishment refers to having a sense of achievement and making progresses.

Researchers have proposed that well-being be characterized as a combination of indicators across multiple domains, rather than as a single factor (Organisation for Economic Co-operation and Development, 2014; Forgeard et al., 2011; Frey \& Stutzer, 2010; Lerner et al., 2009; Keyes, 2007; Ryff \& Keyes, 1995). Baumeister et al. (2013) propose that Subjective Well Being is happiness, which is 'an experiential state of positive affect'. They are of the view that subjective well being can be measured in two different ways i.e. affect balance and life satisfaction.

Subjective well being is defined as an individual's cognitive and affective assessments regarding their life satisfaction (Diener, 1984). Diener et al. (2006) aver that subjective well-being is one's

evaluations of their own lives, which can comprise their judgments about their life satisfaction and evaluations based on personal feelings. Diener (2006) says that subjective well being is an umbrella term encompassing negative and positive evaluations made by an individual about their life satisfaction, engagement and affect. Research evidence suggests that subjective well being is contingent upon life satisfaction including positive and negative affect (Robbins \& Kliewer, 2000; Lightsey, 1996).

(C) The International Journal of Indian Psychology, ISSN 2348-5396 (e)| ISSN: 2349-3429 (p) | 41 


\section{Effects of Materialism on Well-Being: A Review}

There are two top-down and bottom-up factors important to subjective well being (Diener, 1984). Diener et al. (1999) list bottom-up factors such as external events, situations, and demographics whereas top-down factors include individual factors (e.g. values and goals) which trigger external events that influence well-being (Diener et al., 1999).

Three different approaches to define subjective well being capture different aspects- life evaluation, hedonic well being and eudemonic well being (Kahneman et al., 2003). Life evaluation implies an individual's perception of quality of his/her life or overall life satisfaction (Cantril, 1965). Hedonic well being implies the feelings/moods as experienced happiness, sadness, anger and stress (Kahneman et al., 2004). Eudemonic well being concentrates on the meaning and purpose of one's life (Ryff et al., 2004).

\section{Theoretical framework}

There are two theoretical perspectives employed by researchers to explain the development of materialistic tendencies in people viz. the socialization perspective and the psychological perspective (Kasser et al., 2004). The socialization perspective stresses upon the influence of socialization agents such as kith and kin, peers, mass media etc in the development of materialistic values. On the other hand, the psychological perspective emphasizes one's circumstances giving rise to certain emotional states which either deter or facilitate the development of materialistic values.

Various theories predict a negative relationship between materialism and subjective well being. According to the self-determination theory (Deci \& Ryan, 2000), goals based on extrinsic reward, may be related to negative subjective well being. This theory (Deci \& Ryan, 1985; 2000) states that the basic needs of individuals are autonomy, competence, and relatedness with others . In contrast to these needs are the extrinsic needs or aspirations, such as financial success, social recognition, having an influential image etc. (Grouzet et al., 2005; Kasser \& Ryan, 1996). Although extrinsic aspirations may be in accord with basic psychological needs to some extent (e.g. having social recognition may be aimed at satisfying needs for relatedness), the pursuit of extrinsic rewards is observed to be less satisfying than the pursuit of intrinsic rewards (Sheldon et al., 2004; Kasser and Ryan, 2001; Deci and Ryan, 2000).

Another theory by Andrew \& Robinson (1991 in Barbera \& Gurhan, 1997), says that the ability to realize one's aspiration has an impact on one's subjective well being. An individual with a high materialistic aspiration but with an inability to realize it will exhibit reduced subjective well being.

Multiple discrepancy model of subjective well-being proposes that individuals compare our experiences or emotions to some standard and this comparison might make them feel unhappy or dissatisfied if and when the resources they have acquired do not match the standard they have in 


\section{Effects of Materialism on Well-Being: A Review}

mind, called a social comparison discrepancy. Also, individuals feel unhappy or dissatisfied if they could access more resources in the past than now, called past comparison discrepancy (Michalos, 1985).

\section{REVIEW OF LITERATURE}

Studies suggest that high level of materialism is linked with low level of well-being (Sirgy et. al., 2013; Burroughs \& Rindfleisch, 2002; Sirgy et al., 1998; Mick 1996; Kasser \& Ryan, 1993; Richins \& Dawson, 1992; Belk 1984; 1985). Kasser and Ryan (1993) revealed that fulfillment of important life goals gives rise to increased life satisfaction. Intrinsic life goals are found to be positively related with subjective well-being whereas extrinsic life goals share a complex relationship with subjective well being (Zawadzka et al., 2015; Martos \& Kop 2012; Rijavec et al., 2006; Skarżyńska, 2003).

Existing body of research demonstrates the adverse effects of materialistic values and goals dominant in consumerist societies (Kasser et al., 2007). The negative relationship between materialism and subjective well-being and other indicators of psychological health are most frequently reported downside of materialism (Kasser \& Kanner, 2004; Dittmar, 2008).

Barbera \& Gürhan (1997) proposed that envy is one aspect of materialism that exerts negative effect on SWB. They observed a negative relationship between non-generosity and envy and subjective well being in evangelical Christians and positively related in non-Christians. This reveals that the conflicting goals of religion and materialism can have a negative impact on subjective well being.

Research evidence abounds to substantiate the argument that people who pursue material goals tend to experience lower subjective well-being (Christopher et al., 2009; Kashdan and Breen, 2007). High materialistic individuals experience more negative feelings and are less satisfied with life and with specific life domains than less materialistic individuals (Christopher et al. 2007; Kashdan \& Breen 2007). Research studies also reveal significantly lower subjective wellbeing in materialistic individuals, irrespective of their incomes (Kasser \& Ahuvia, 2002; Kasser \& Ryan, 1996).

Some scholars propose that materialistic individuals exhibit less satisfaction because they tend to set higher standards for their lives (Shaw et al., 2004; Goldberg et al., 2003). In studies conducted in different countries materialism was found to be related with dissatisfaction with life and lower subjective well-being (Dittmar et al. 2014; Roberts et al. 2005; Keng et al. 2000; Wright \& Larsen 1993; Richins \& Dawson 1992; Dawson \& Bamossy, 1991; Belk, 1985; 1984). Dittmar et al. (2014) proposed that materialism is related to a number of well-being indicessubjective wellbeing, positive self-appraisals, psychopathology, and physical health. In various studies, materialists are found to be less happier and more dissatisfied with life than nonmaterialists (Chang \& Arkin, 2002; Belk, 1985), and they are also found to experience more physical and psychological ailments (Kasser, 2002).

(c) The International Journal of Indian Psychology, ISSN 2348-5396 (e) | ISSN: 2349-3429 (p) | 43 


\section{Effects of Materialism on Well-Being: A Review}

Materialism has been found to be positively related to psychological illnesses such are paranoia and depression (Kasser \& Ryan, 1993). Individuals scoring high on materialism are observed to be concerned with outward appearances, and motivated by the extrinsic goals (Kasser \& Ahuvia, 2002).

Studies examined the effects of possessions on individuals and found that in individuals who place emphasis on acquiring goods exhibit psychological maladjustment and lowered well being. In addition to this, the individuals in quest of their identity through consumption tend to sacrifice altruism (Kasser et al .2007; 2002). Belk (1985) found a negative relationship between materialism and happiness and life satisfaction. Burroughs \& Rindfleisch (2002) found a negative relationship between the number of possessions listed on a consumer's wish list and his life satisfaction.

Myriads of studies have confirmed the negative relationship between materialism and well-being measures such as life satisfaction and happiness (Diener 2009; Kashdan \& Breen 2007; Ahuvia \& Wong 2002; Burroughs \& Rindfleisch, 2002; Tatzel 2002). Researchers examining the extrinsic life goals are attracted by 'materialistic triad' comprising fame, wealth and image and they found that these goals are associated with lower levels of life satisfaction (Kasser, 2002). Other studies have investigated the association of positive and negative affect (domains of well being) with the level of materialism (Hudders \& Pandelaere, 2012; Christopher et al., 2009; Christopher \& Schlenker, 2004). The results revealed that materialistic individuals reported experiencing more negative affect. Christopher and Schlenker (2004) found a negative impact of materialism on positive affect.

Delhey (2010) states "happiness tends to be pretty materialist in poorer places and more postmaterialist in richer ones". Comparing the data obtained from 48 countries, he showed that income and material possessions are considered more important and central to personal quality of life in poorer countries than in richer ones.

A meta- analysis conducted by Dittmar et al. (2014) on the relationship between materialism and personal well being examined the effect sizes from a large number of independent studies and reported that materialism was negatively associated with well being. The largest detrimental effects were observed for various well being outcomes (risky health, consumer behavior and negative self appraisal) whereas the weakest effects were observed for life satisfaction and negative affect.

\section{When Materialism is not detrimental to Well Being}

Despite the cacophony about negative relationship between Materialism and Well-Being of an individual, it is interesting to note that there are studies that have shown contradictory results. It has been observed that striving for extrinsic goals for autonomous reasons feels less satisfying than autonomously striving for intrinsic goals (Sheldon et al., 2004). Some researchers 


\section{Effects of Materialism on Well-Being: A Review}

investigating the interaction of income with materialism and well being reported that higher income might cushion the negative impact of materialism on subjective well-being of the individuals (Nickerson et al., 2003). There is research evidence to suggest that it is not material acquisition which contributes to reduced wellbeing in an individual, but the material acquisition guided by extrinsic aspirations is the source behind reduced well being (Garðarsdóttir et al., 2009).

\section{CONCLUSION, LIMITATION AND RESEARCH DIRECTIONS}

Materialism has drawn considerable attention of scholars in the field of positive psychology because of its negative relationship with well being indices. The main theme of the paper is that materialistic tendencies can have a detrimental effect on well being. King et al. (2004) stated that there are many ways leading to a well-lived life and people do have a sense of what it takes to make for a fulfilled life. And despite the evidence available to the contrary, people persistently behave in ways that contradict these intuitions and pursue materialistic goals rather than pursue goals that may be more beneficial for their well-being. Interestingly, there is research evidence available that suggests that the relationship between materialism and well being is moderated by the income.

It is imperative to conduct researches examining the relationship between materialistic orientations and well being in Indian scenario considering demographic factors such as gender, age, study and work environment (with a special focus on public and private sector). Thus this paper proffers a need to understand this intricate relationship through theoretical as well as empirical approach. And while examining this relationship, it should be kept in mind that different cultures and economies can influence the meaning of materialism and attitude towards materialistic goals within a society. There is a pressing need to advance longitudinal and developmental researches in this area.

The major limitation of this paper is that it is a theoretical paper and aims to understand the intricacies involved in materialistic pursuit and the well being of the materialistic individuals through review of literature.

\section{REFERENCES}

Ahuvia, A. C. \& Wong, N.C. (2002). Personality and values based materialism: Their relationship and origins. Journal of Consumer Psychology, 12 (4), 389-402.

Andrews, F. M. \& Robinson, J. P. (1991). Measures of subjective well-being, In J.P. Robinson, P.R. Shaver, \& L.R. Wrightsman (Eds.), Measures of Personality and Social Psychological Attitudes, (pp. 61-114). San Diego: Academic Press.

Andrews, F. M. \& Withey, S.B. (1976). Social Indicators of Well-Being: Americans' Perceptions of Life Quality. New York: Plenum.

Appadurai, A. (1990). Disjuncture and difference in the global cultural economy. In Featherstone, M. (Ed.), Global Culture: Nationalism, Globalization and Modernity, (pp. 295-319). Sage: London.

(C) The International Journal of Indian Psychology, ISSN 2348-5396 (e)| ISSN: 2349-3429 (p) | 45 


\section{Effects of Materialism on Well-Being: A Review}

Arndt, J., Solomon, S., Kasser, T., \&. Sheldon, K.M. (2004). The urge to splurge revisited: Further reflections on applying terror management theory to materialism and consumer behavior. Journal of Consumer Psychology, 14(3), 225-229.

Arndt, J., Solomon, S., Kasser, T., \&. Sheldon, K.M. (2004). The urge to splurge: A terror management account of materialism and consumer behavior. Journal of Consumer Psychology, 14(3), 198-212.

Astin, A.W., Oseguera, L., Sax, L.J., \& Korn, W.S. (2002). The American Freshman: 35 Year Trends. Los Angeles: UCLA Higher Education Research Institute.

Baumeister, R. F., Vohs, K. D., Aaker, J. L., \& Garbinsky, E. N. (2013). Some key differences between a happy life and a meaningful life. Journal of Positive Psychology. 8 (6), 505516.

Belk, R. W. (1985). Materialism: Trait aspects of living in the material world. Journal of Consumer Research, 12(4), 265-280.

Belk, R.W. (1984). Three scales to measure constructs related to materialism: reliability, validity and relationships to measures of happiness. In: Kinner TF (Ed.) (pp.291-297). Advances in Consumer Research, Ann Arbor MI: Association for Consumer Research.

Belk, R.W. Possessions and the extended self. Journal of Consumer Research,11, 139-168.

Bindah, E.V., \& Othman, M.N. (2011). The role of family communication and television viewing in the development of materialistic values among young adults: a review. International Journal of Business and Social Sciences, 2 (3), 238-248.

Brewer, J., \& Porter, R. (1993). Introduction. In J. Brewer \& R. Porter (Eds.), Consumption and the World of Goods (pp. 1-15). New York: Routledge.

Burroughs, J. E., \& Rindfleisch, A. (1997). Materialism as a coping mechanism: An inquiry into family disruption. Advances in Consumer Research, 24, 89-97.

Burroughs, J. E., \& Rindfleisch, A. (2002). Materialism and well-being: A conflicting values perspective. Journal of Consumer Research, 29 (12), 348-70.

Burroughs, W. J., Drews, D. R., \& Hallman, W. K. (1991). Predicting personality from personal possessions: A self-presentational analysis. Journal of Social Behavior and Personality, 6(6), 147-163.

Burroughs, W.J., Drews, D.R. \& Hallman, W.K. (1991). Predicting personality from personal possessions: A self-presentational analysis. Journal of Social Behavior and Personality, 6 (6), 147-163.

Cantril, H. (1965). The Pattern of Human Concerns. New Brunswick, NJ: Rutgers University Press.

Chang, L., \& Arkin, R. M. (2002). Materialism as an attempt to cope with uncertainty. Psychology and Marketing, 19, 389-406.

Christopher, A. N., Lasane, T. P., Troisi, J. D., \& Park, L. E. (2007). Materialism, defensive and assertive self-presentational styles, and life satisfaction. Journal of Social and Clinical Psychology, 26(10), 1146-1163.

Christopher, A. N., Saliba, L., \& Deadmarsh, E. J. (2009). Materialism and well-being: The mediating effect of locus of control. Personality and Individual Differences, 46(7), 682686.

Christopher, A.N, \& Schlenker, B.R. (2004). Materialism and affect: the role of selfpresentational concerns. Journal of Social and Clinical Psychology,23, 260-272. doi: 10.1521/jscp.23.2.260.31022. 


\section{Effects of Materialism on Well-Being: A Review}

Craig, C.S. \& Douglas, S.P. (2006). Beyond national culture: implications of cultural dynamics for consumer research. International Marketing Review, 23 (3), 322-42.

Craig, C.S., Douglas, S.P. \& Bennet, A. (2009). Contextual and cultural factors underlying Americanization. International Marketing Review, 26 (1), 90-109.

Csikszentmihalyi, M. (1999). If we are so rich, why aren’t we happy?. American Psychologist, 54, 821-827.

Dawson, S, \& Bamossy, G. (1991). If “We are what we have” what are we when we don't have? An exploratory study of materialism among expatriate Americans. Journal of Social Behaviour and Personality, 6, 363-381.

De G., J., Wann, D. \& Naylor, T. (2005). Affluenza. San Francisco: Berrett-Koehler Press.

De, G. J., Wann, D., Naylor, T. H., \& Redefining Progress (Organization). (2001). Affluenza: The all consuming epidemic. San Francisco, CA: Berrett-Koehler Publishers.

Deci, E.L. \& Ryan, R.M. (1985). Intrinsic motivation and self determination in human behavior. New York: Plenum.

Deci, E.L. \& Ryan, R.M. (2000). The 'what' and 'why' of goal pursuits: Human needs and the self-determination of behavior. Psychological Inquiry, 11 (4), 227-268.

Delhey, J. (2010). From materialist to post-materialist happiness? National affluence and determinants of life satisfaction in cross-national perspective. Social Indicators Research, 97, 65-84. doi: 10.1007/s11205-009-9558-y.

Diener, E, Lucas, R, \& Scollon, C. N. (2006). Beyond the hedonic treadmill: revising the adaptation theory of well-being. American Psychology, 61, 305-314. doi: 10.1037/0003066X.61.4.305.

Diener, E. (1984). Subjective well-being. Psychological Bulletin, 95, 542-575.

Diener, E. (2006). Guidelines for national indicators of subjective well-being and ill-being. Journal of Happiness Studies, 7, 397-404.

Diener, E. (2009). The Science of Well-being. New York: Springer.

Diener, E., Sandvik, E., Seidlitz, L., \& Diener, M. (1993). The relationship between income and subjective well-being: Relative or absolute? Social Indicators Research, 28, 195-223.

Diener, E., Suh, E., Lucas, R. \& Smith, H. (1999). Subjective well being: Three decades of progress. Psychological Bulletin, 125, 276-302.

Dittmar, H. \& Drury, J. (2000). Self-image - is it in the bag? A qualitative comparison between 'ordinary' and 'excessive' consumers. Journal of Economic Psychology, 21 (2), 109_ 142.

Dittmar, H. (1992). The social psychology of material possessions: To have is to be. Harvester Wheatsheaf: St. Martin's Press.

Dittmar, H. (2007). The costs of consumer culture and the 'cage within': The impact of the material 'good life' and 'body perfect' ideals on individuals' identity and well-being. Commentary on Kasser, T. Cohn, S., Kanner, A. D., \& Ryan, R. M. (2006). Some costs of American corporate capitalism: A psychological exploration of value and goal conflicts. Psychological Inquiry, 18, 1-9.

Dittmar, H. (2008). Consumer culture, identity, and well-being: The search for the 'good life' and the 'body perfect'. Hove \& New York: Psychology Press.

Dittmar, H., \& Pepper, L. (1994). To have is to be: Materialism and person perception in working-class and middle-class British adolescents. Journal of Economic Psychology, 15(2), 233-251. 


\section{Effects of Materialism on Well-Being: A Review}

Dittmar, H., Bond, R., Kasser, T., \& Hurst, M. (2014). The relationship between materialism and personal well-being: A meta-analysis. Journal of Personality and Social Psychology, 107(5), 879-924.

Douglas, S.P. \& Craig, C.S. (1997). The changing dynamic of consumer behavior: implications for cross-cultural research. International Journal of Research and Marketing, 14, 379-95.

Eckersley R. (2005). Well and Good: Morality, Meaning and Happiness. 2nd edn. Melbourne: Text Publishing.

Eckersley, R.(2001). Culture, health and well-being. In: Eckersley R, Dixon J, Douglas B (Eds.) The Social Origins of Health and Well-being, (pp.51-70). Cambridge: Cambridge University Press.

Faber, R. J. \& O'Guinn, T.C. (1989). Classifying Compulsive Consumers: Advances in the Development of a Diagnostic Tool. In T. K. Srull (Ed.), Advances in Consumer Research (pp.745-748) UT: Association for Consumer Research.

Forgeard, M. J. C., Jayawickreme, E., Kern, M. L., \& Seligman, M. E. P. (2011). Doing the right thing: Measuring wellbeing for public policy. International Journal of Wellbeing, 1, 79106. doi:10.5502/ijw.v1i1.15

Fransen, M., Fennis, B., Pruyn, A., \& Das, E. (2008). Rest in peace? Brand-induced mortality salience and consumer behavior. Journal of Business Research, 61(10), 1053-1061.

Frey, B. S., \& Stutzer, A. (2010). Happiness and public choice. Public Choice, 144, 557-573. doi:10.1007/s11127-010-9681-y

Garðarsdóttir, R. B., \& Dittmar, H. (2012). The relationship of materialism to debt and financial well-being: The case of Iceland's perceived prosperity. Journal of Economic Psychology, 33, 471-481.

Garðarsdóttir, R. B., Dittmar, H., \& Aspinall, C. (2009). It's not the money, it's the quest for a happier self: The role of happiness and success motives in the link between financial goal importance and subjective well-being. Journal of Social and Clinical Psychology, 28, $1100-1127$.

Ger, G. \& Belk, R.W. (1985). Cross-Cultural Differences in Materialism. Journal of Economic Psychology, 17 (1), 55-77.

Ger, G. \& Belk, R.W. (1996). Cross-cultural differences in materialism. Journal of Economic Psychology, 17 (1), 55-77.

Ger, G., \& Belk, R. W. (1999). Accounting for materialism in four cultures. Journal of Material Culture, 4(2), 183-204.

Ghadrian, A. M. (2010). Materialism: Moral and Social Consequences. Oxford: George Ronald.

Goldberg, M. E., Gorn, G. J., Peracchio, L. A., \& Bamossy, G. (2003). Understanding materialism among youth. Journal of Consumer Psychology, 13(3), 278-288.

Grouzet, F. M. E., Kasser, T., Ahuvia, A., Dols, J. M. F., Kim, Y., Lau, S., ..... Sheldon, K. M. (2005). The structure of goal contents across 15 cultures. Journal of Personality and Social Psychology, 89(5), 800-816.

Holt, D. B. (1998). Does cultural capital structure American consumption? Journal of Consumer Research, 25 (1), 1-25.

Hudders L, \& Pandelaere, M. (2012). The silver lining of materialism: the impact of luxury consumption on subjective well-being. Journal of Happiness Studies, 13, 411-437. doi: 10.1007/s10902-011-9271-9.

Kahneman, D., Diener, E., \& Schwarz, N. (2003). Well-Being: The Foundations of Hedonic Psychology. New York: Russel Sage Foundation. 


\section{Effects of Materialism on Well-Being: A Review}

Kahneman, D., Krueger, A.B., Schkade, D.A., Schwarz, N., \& Stone, A.A. (2004). A survey method for characterizing daily life experience: The day reconstruction method. Science, 306, 1776-80.

Kamptner, N. L. (1991). Personal possessions and their meanings: A life-span perspective. Journal of Social Behavior and Personality, 6(6), 209-228.

Kashdan, T. B., \& Breen, W. E. (2007). Materialism and diminished well-being: Experiential avoidance as a mediating mechanism. Journal of Social and Clinical Psychology, 26, 521-539.

Kasser, S., Cohn, A.D., Kanner, R., \& Ryan, M. (2007). Some costs of American corporate capitalism: A psychological exploration of value and goal conflicts. Psychological Inquiry, 18, 1-22.

Kasser, T. (2002). The High Price of Materialism. Cambridge, MA: MIT Press.

Kasser, T., \& Ahuvia, A. C. (2002). Materialistic values and wellbeing in business students. European Journal of Social Psychology, 32, 137-146.

Kasser, T., \& Kanner, A. (2004). Where is the psychology of consumer culture? In T. Kasser \& A. Kanner (Eds.), Psychology and consumer culture: The struggle for a good life in a materialistic world (pp. 3-7). Washington, D.C.: American Psychological Association.

Kasser, T., \& Ryan, R. M. (1993). A dark side of the American dream: Correlates of financial success as a central life aspiration. Journal of Personality and Social Psychology, 65, 410-422.

Kasser, T., \& Ryan, R. M. (1996). Further examining the American dream: Differential correlates of intrinsic and extrinsic goals. Personality and Social Psychology Bulletin, 22, 281-288.

Kasser, T., \& Ryan, R.M. (2001). Further examining the American dream: Differential correlates of intrinsic and extrinsic goals. Personality and Social Psychology Bulletin, 3, 280-287

Kasser, T., Ryan, R. M., Couchman, C. E., \& Sheldon, K. M. (2004). Materialistic values: Their causes and consequences. In T. Kasser \& A. D. Kanner (Eds.), Psychology and consumer culture: The struggle for a good life in a materialistic world (pp. 11-28). Washington, DC: American Psychological Association.

Keng. K.A, Jung, K, Jiuan, T.S., \& Wirtz, J.(2000). The influence of materialistic inclination on values, life satisfaction and aspirations: an empirical analysis. Social Indicators Research, 59, 317-333. doi: 10.1023/A:1006956602509.

Keyes, C. L. M. (2007). Promoting and protecting mental health as flourishing: A complementary strategy for improving national mental health. American Psychologist, 62, 95-108. doi:10.1037/0003-066X.62.2.95

King, L. A., Eells, J. E., \& Burton, C. M. (2004). The good life, broadly defined. In A. Linley \& S. Joseph (Eds.), Positive Psychology in Practice (pp. 35-52). Hoboken, New Jersey: John Wiley and Sons.

La Barbara, P. A. \& Gurhan, Z. (1997). The role of materialism, religiosity, and demographics in subjective well-being. Psychology and Marketing, 14 (1), 71-97.

Larsen, V., Sirgy, M. J., \& Wright, N. D. (1999). Materialism: The construct, measures, antecedents, and consequences. Academy of Marketing Studies Journal, 3 (2), 78-110.

Lerner, J. V., Phelps, E., Forman, Y., \& Bowers, E. P. (2009). Positive youth development. In R. M. Lerner \& L. Steinberg (Eds.), Handbook of Adolescent Psychology (3rd ed., pp. 524558). New York, NY: Wiley. 


\section{Effects of Materialism on Well-Being: A Review}

Levy, S. J. (1981). Interpreting consumer mythology: A structural approach to consumer behavior. Journal of Marketing, 45, 49-61.

Lightsey, O.R. (1996). What leads to wellness? The role of psychological resources in well being. Counselling Psychoogy., 24 (4), 589-735. doi: 10.1177/0011000096244002.

Lim, W. M., Ting, D. H., Khoo, P. T., \& Wong, W. Y. (2012). Understanding consumer values and socialization - A case of luxury products. Management \& Marketing, 7 (2), 209-220.

Malhotra, N. K. (2006). Consumer well-being and quality of life: An assessment and directions for future research. Journal of Macromarketing, 26 (1), 77-80.

Martos, T., \& Kopp, M. S. (2012). Life goals and well-being: Does financial status matter? Evidence from a representative Hungarian sample. Social Indicators Research, 105, 561568.

McCracken, G. (1986). Culture and Consumption: A theoretical account of the structure and movement of the cultural meaning of consumer goods. Journal of Consumer Research, 13 (6), 71-84.

Michalos, A. C. (1985). Multiple discrepancies theory (MDT). Social Indicators Research, 16, 347-413.

Mick, D. G. (1996). Are studies of dark side variables confounded by socially desirable responding? The case of materialism. Journal of Consumer Research, 23, 106-119.

Mickens, K. \& Roberts, S.D. (1999). Desperately seeking certainty: Narrowing the materialism construct. Advances in Consumer Research, 36 (1), 513-518.

Nickerson, C., Schwarz, N., Diener, E., \& Kahneman, D. (2003). Zeroing the dark side of the American Dream: a closer look at the negative consequences of the goal for financial success. Psychological science. 2003, 14(6), 531-536.

Organisation for Economic Co-operation and Development. (2014). OECD better life index executive report. Retrieved from http://www.oecdbetterlifeindex.org/media/bli/documents/LI_executive_summary_2014.p $\mathrm{df}$

Parker, R. S., Haytko, D., \& Hermans, C. (2010). The perception of materialism in a global market: A comparison of younger Chinese and United States consumers. Journal of International Business and Cultural Studies, 3, 1-13.

Prendergast, G., \& Wong, C. (2003). Parental influence on the purchase of luxury brands of infant apparel: An exploratory study in Hong Kong. Journal of Consumer Marketing, 20(2), 157-169.

Ramanathan, S. \& Menon, G. (2006). Time-Varying Effects of Chronic Hedonic Goals on Impulsive Behavior. Journal of Marketing Research, 18, 628-641.

Richins, M. \& Rudmin, F.W. (1994). Materialism and economic psychology. Journal of Economic Psychology, 15, 217-231.

Richins, M. L. (1994a). Special possessions and the expression of material values. Journal of Consumer Research, 21 (6), 522-31.

Richins, M. L. (1994b). Valuing Things: The public and private meaning of possessions. Journal of Consumer Research, 21 (6), 504-21.

Richins, M. L. (2004). The material values scale: Measurement properties and development of a short form. Journal of Consumer Research, 31(1), 209-219.

Richins, M. L., \& Dawson, S. (1992). A consumer values orientation for materialism and its measurement: Scale development and validation. Journal of Consumer Research, 19(3), 303-316. 


\section{Effects of Materialism on Well-Being: A Review}

Rijavec, M., Brdar, J., \& Mijković, D. (2006). Extrinsic vs. intrinsic life goals and well-being. In A. Delle Fave (Eds.), Dimensions of well-being: research and interventions (pp. 91-103). Milano: Franco Angeli.

Rindfleisch, A., \& Burroughs, J. (2004). Terrifying thoughts, terrible materialism? Contemplations on a terror management account of materialism and consumer behavior. Journal of Consumer Psychology, 14(3), 219-224.

Robbins, S. B, \& Kliewer, W.L. (2000). Advances in theory and research on subjective wellbeing. In: Brown SD, Lent RW, editors. Handbook of Counseling Psychology. $\left(3^{\text {rd }}\right.$ ed.pp.310-345). New York, NY: John Wiley \& Sons, Inc.

Roberts, J.A., Tanner J.F., \& Manolis, C. (2005). Materialism and the family structure-stress relation. Journal of Consumer Psychology, 15, 183-190. doi: 10.1207/s15327663jcp1502_10.

Russell, B. (1916). The principle of social reconstruction. G. Allen \& Unwin Ltd.: London.

Ryff, C. D., \& Keyes, C. L. M. (1995). The structure of psychological well-being revisited. Journal of Personality and Social Psychology, 69, 719-727. doi:10.1037/00223514.69.4.719

Ryff, C.D., Singer, B.H., \& Dienberg, L.G. (2004). Positive health: Connecting well being with biology. Philosophical Transactions of the Royal Society of London, 359, 1383-1394.

Schaefer, A. D., Hermans, C. M., \& Parker, R. S. (2004). A cross-cultural exploration of materialism in adolescents. International Journal of Consumer Studies, 28 (4), 399-411.

Schor, J., \& Holt, D. B. (Eds.). (2000). The consumer society reader. New York: The New Press.

Schudson, M. (1991). Delectable materialism: Were the critics of consumer culture wrong all along?. American Prospect, 2, 26-35.

Scott, K., Diane, M. M., \& Schouten, J.W. (2014). Marketing and the New Materialism. Journal of Macromarketing, 34 (3), 282-290.

Seligman, M. E. P. (2011). Flourish. New York, NY: Simon \& Schuster.

Seligman, M. E. P., \& Csikszentmihalyi, M. (2000). Positive psychology: An introduction. American Psychologist, 55, 5-14. doi:10.1037/0003-066X.55.1.5

Shaw, J. W., Leung, A., \& Wallendorf, M. (2004). The positive and negative consequences of materialism: What are they and when do they occur? Advances in Consumer Research, 31, 232-235.

Sheldon, K. M., Ryan, R.M., Deci, E.L., \& Kasser, T. (2004).The independent effects of goal contents and motives on well-being: It's both what you pursue and why you pursue it. Personality and Social Psychology Bulletin, 30 (4), 475-486.

Sirgy, M. J. \& Lee, D. (2006). Macro measures of consumer well-being (CWB): A critical analysis and a research Agenda. Journal of Macromarketing, 26 (1), 27-44.

Sirgy, M. J. (1998). Materialism and quality of life. Social Indicators Research,43, 227-260. doi: 10.1023/A:1006820429653.

Sirgy, M. J., Gurel-Atay, E., Webb, D., Cicic, M., Husic-Mehmedovic, M., Ekici, A., ... Johar, J. S. (2013). Is materialism all that bad? Effects on satisfaction with material life, life satisfaction, and economic motivation. Social Indicators Research, 110(1), 349-366.

Solomon, S., Greenberg, J., \& Pyszczynski, T. (2004). Lethal consumption: Death-denying materialism. In T. Kasser \& A. D. Kanner (Eds.), Psychology and consumer culture: The struggle for a good life in a materialistic world (pp. 127-146). Washington, DC: American Psychological Association. 


\section{Effects of Materialism on Well-Being: A Review}

Tatzel, M. (2002). Money worlds and well-being: An integration of money dispositions, materialism and price-related behavior. Journal of Economic Psychology, 23 (1), 103126.

Twitchell, J. B. (1999). Two cheers for materialism. The Wilson Quarterly, 23 (2),16-26.

Van Boven, L. \& Gilovich, T. (2003). To Do or to Have? That is the question. Journal of Social Psychology. 85 (6), 1193-1202.

Widemann, K.P., Hennigs, N. \& Siebels, A. (2009). Value-based segmentation of luxury consumption behaviour. J. Psychol. Mark., 26, 625-651.

Wong, N. Y., \& Ahuvia, A. C. (1998). Personal taste and family face: Luxury consumption in Confucian and Western societies. Psychology and Marketing, 15(5), 423-441.

Wright, N.D., \& Larsen, V. (1993). Materialism and life satisfaction: a Meta-Analysis. Journal of Consumer Satisfaction, Dissatisfaction and Complaining Behaviour, 6, 158-165.

Zawadzka, A.M., Duda, J., Rymkiewicz, R. \& Blanka Kondratowicz- Nowak, B. (2015). Siedmiowymiarowy model aspiracji życiowych Kassera i Ryana: analiza trafności i rzetelności narzędzia [Seven-dimensional model of life aspirations by Kasser and Ryan: analysis of validity and reliability of the instrument]. Psychologia Społeczna, in press.

How to cite this article: H Kaur, R Kaur (2016), Effects of Materialism on Well-Being: A Review, International Journal of Indian Psychology, Volume 3, Issue 4, No. 56, ISSN 2348-5396 (e) | ISSN: 2349-3429 (p), DIP: 18.01.005/20160304, ISBN: 978-1-365-23992-2 